\title{
ACUTE MYOCARDIAL INFARCTION WITH VITAMIN B12 DEFICIENCY AND MILD HYPERHOMOCYSTEINEMIA: A CASE REPORT AND REVIEW
}

\author{
SIDDHI UMARJE ${ }^{1}$, PANDA BK ${ }^{1}$, MADHU BANSODE ${ }^{2}$ \\ ${ }^{1}$ Department of Clinical Pharmacy, Poona College of Pharmacy, Bharati Vidyapeeth University, Pune, Maharashtra - 411046 , India. \\ ${ }^{2}$ Department of Medicine, Bharati Medical College and Hospital, Bharati Vidyapeeth University, Pune, Maharashtra - 411 046, India. \\ Email: bijoymaximus@gmail.com
}

Received: 02 July 2016, Revised and Accepted: 05 July 2016

\section{ABSTRACT}

A 38-year-old male was diagnosed with acute myocardial infarction (AMI) without a history of any significant clinical conditions. His subjective complaints and objective findings were clearly suggesting an acute ischemic attack along with vitamin B12 deficiency. While managing him for AMI, serology tests for vitamin B12 revealed low levels along with the mild elevation of serum homocysteine level. He was managed with thrombolytic agent, $\beta$-adrenergic blocker, aspirin, antiplatelet agents, anticoagulants, statin, vitamin B complex, and folic acid supplements. The clinical pharmacist intervened by suggesting discontinuation of clopidogrel as two antiplatelet agents (clopidogrel and ticagrelor) were administered along with an anticoagulant, thereby increasing the risk of bleeding in the patient. Clopidogrel was stopped as ticagrelor is a better antiplatelet agent when given in combination with low dose aspirin. Furthermore, aspirin dose was reduced to enhance the efficacy of ticagrelor and provide better secondary prevention for vascular diseases.

Keywords: Vitamin B12 deficiency, Hyperhomocysteinemia, Acute myocardial infarction, Clinical pharmacist intervention.

(C) 2016 The Authors. Published by Innovare Academic Sciences Pvt Ltd. This is an open access article under the CC BY license (http://creativecommons. org/licenses/by/4. 0/) DOI: http://dx.doi.org/10.22159/ajpcr.2016.v9i6.13841

\section{INTRODUCTION}

Homocysteine ( $\mathrm{HCY})$ is an intermediate product formed during the intracellular metabolism of dietary methionine which requires folic acid, vitamin B12, and vitamin B6 for its catabolism. Deficiency of vitamin B12 can lead to saturation of HCY causing hyperhomocysteinemia [1]. This HCY has direct toxic effects on vascular vessel walls due to the generation of oxidative free radicals. Generation of such oxidative free radicals initiates atherogenesis. A chain of reactions takes place due to the oxidative free radicals causing endothelial injury which promotes atherosclerosis. Several studies have identified hyperhomocysteinemia as a risk factor for coronary artery syndromes [2-6].

Few case reports were published on hyperhomocysteinemia as a risk factor for coronary artery syndromes in young adult patients. We present a case of 38-year-old male diagnosed with acute myocardial infarction (AMI) subsequently with vitamin B12 deficiency and mild hyperhomocysteinemia. A comparative case report evaluation has been conducted to identify the differences and similarities in clinical presentation, laboratory investigation reports, and management.

\section{CASE REPORT}

A 38-year-old man with no significant medical history presented with complaints of chest pain, sweating, nausea, tingling in both the upper limbs, and backache. He was transferred from a primary health-care setting and was admitted to a tertiary care hospital. Electrocardiogram (ECG) done at the primary health-care setting provided an impression of ST-segment elevation suggestive of hyper-AMI. Another ECG done on admission to the tertiary care hospital revealed ST-segment elevation with lateral wall of left ventricle hypokinetic and moderate left ventricular systolic dysfunction. He was otherwise vitally stable, conscious, and oriented. The patient suffered from jaundice 3 years back and had a family history of ischemic heart disease but no other co-morbid conditions. The patient was a non-smoker and followed the Mediterranean diet.
Laboratory tests performed on admission revealed a platelet count of 247,000/cmm; hemoglobin level $15.1 \mathrm{~g} / \mathrm{dL}$, borderline high red blood cells (RBC) indices, and RBC morphology were normal, thus showing no signs of anemia. Liver function tests were normal. Lipid profile revealed serum cholesterol $186 \mathrm{mg} / \mathrm{dL}$ and serum low-density lipoproteins cholesterol $129.8 \mathrm{mg} / \mathrm{dL}$, which was considered to be normal. Cardiac enzymes were checked and were found to be highly elevated (troponin I $0.54 \mathrm{ng} / \mathrm{ml}[0-0.04 \mathrm{ng} / \mathrm{ml}]$, serum creatinine phosphokinase [CPK] 457 IU/L [25-200 IU/L], and CPK-MB 38 IU/L [0-25 IU/L]] suggesting an ischemic attack.

Treatment was initiated with injection streptokinase 25,000 IU to thrombolysis and recanalize the occluded artery, and the patient was prescribed with on the tablet. Metoprolol $25 \mathrm{mg}$ twice daily, tablet. Aspirin $150 \mathrm{mg}$ once daily, tablet. Clopidogrel $75 \mathrm{mg}$ twice daily, tablet. Atorvastatin $80 \mathrm{mg}$ once daily at night, tablet. Nicorandil $5 \mathrm{mg}$ twice daily along with injection. Ondansetron $4 \mathrm{mg}$ thrice in a day and tablet. Alprazolam $0.5 \mathrm{mg}$ once daily at night. Coronary angiography revealed recanalized left anterior descending coronary artery having a slow blood flow requiring medical management. Thus, on day 2, tablet. Ticagrelor (90 mg) twice daily and a low molecular weight heparin (injection enoxaparin $60 \mathrm{mg} / 0.6 \mathrm{ml}$ ) were added to improve the coronary artery blood flow. Chest pain, nausea, sweating, and backache were resolved completely by day 3 , but the tingling sensation persisted. Thus, suspecting a vitamin B12 deficiency, the patient's serum vitamin B12 and HCY levels were checked which revealed vitamin B12 level as $89 \mathrm{pg} /$ $\mathrm{ml}(187-883 \mathrm{pg} / \mathrm{ml})$ and serum HCY as $15.65 \mu \mathrm{mol} / \mathrm{L}(0-15 \mu \mathrm{mol} / \mathrm{L})$. Hence, this confirmed vitamin B12 deficiency with mild elevation of HCY levels. The patient was immediately put on oral supplementation of vitamin B12 (1.5 mg) + vitamin B6 (20 mg) + folic acid (5 mg) once daily. He was discharged on day 5 and was continued on atorvastatin, nitrate, vitamin B complex, ticagrelor, and aspirin at a low dose (100 mg). He was asked to visit the hospital for a follow-up after 2 weeks.

We have conducted a search on AMI, vitamin B12 deficiency, and hyperhomocysteinemia. Pertinent case reports were searched 
for in PubMed for "AMI" and "vitamin B12 deficiency," or "hyperhomocysteinemia." Articles were limited to case reports and English language. The search strategy was set until the end of April 2016. The clinical reports showing patient diagnosed with AMI having vitamin B12 deficiency and hyperhomocysteinemia without any comorbid conditions such as diabetes, hypertension, hyperlipidemia, and obesity were compared for similarities and differences with our case.

Table 1 gives abriefcomparison between ourcase and similar published case reports of AMI with vitamin B12 deficiency and hyperhomocysteinemia.

\section{DISCUSSION}

Hyperhomocysteinemia is defined as a medical condition characterized by an abnormally high level ( $>15 \mu \mathrm{mol} / \mathrm{L})$ of HCY in blood. It is classified as moderate $(16-30 \mu \mathrm{mol} / \mathrm{L})$, intermediate $(31-100 \mu \mathrm{mol} / \mathrm{L})$, and severe $(>100 \mu \mathrm{mol} / \mathrm{L})$ hyperhomocysteinemia [11]. Elevated plasma HCY levels can be caused by a number of factors, including folate and vitamin B12 deficiency, pre-existing atherosclerotic disease, diabetes, and various drugs [12]. Mild elevation in HCY level is associated with the low levels of vitamin B12 and enhances the formation of atherosclerotic plaque. Thus, it is a risk factor for major vascular events. The threshold level for elevated values of plasma HCY in males is $11.4 \mu \mathrm{mol} / \mathrm{L}$. Above this level, there is a risk of formation of atherosclerotic plaque $[13,14]$. Few epidemiological studies conducted in India has reported a high prevalence of elevated plasma HCY level in the study population $[15,16]$

Case 1 [7] and Case 2 [8] mentioned that the patient complained of paresthesia which was observed in our case too. The patients were $[7,8]$ diagnosed with pernicious anemia suggesting the etiology behind vitamin B12 deficiency. Case 3 [9] and Case 4 [10] did not report any subjective complaints of vitamin B12 deficiency at the time of hospital admission irrespective of low serum vitamin B12 level. When Case 2 [8] was compared with our case, it was found that the serum vitamin B12 level in the patient [8] was comparatively higher $(158 \mathrm{pg} / \mathrm{ml})$ but had severe hyperhomocysteinemia (serum HCY: $105 \mu \mathrm{mol} / \mathrm{L}$ ). The striking difference was of the presence of pernicious anemia in the reported case [8]. Thus, it is difficult to establish a relationship between the severity of vitamin B12 deficiency and the degree of hyperhomocysteinemia (moderate/intermediate/severe). Furthermore, one of the significant differences between our case and all the published case reports [7-10] was the finding of hemoglobin level. The arithmetic mean of hemoglobin levels found in patients reported in all the case reports was found to be $10.85 \mathrm{~g} / \mathrm{dL}$. This calculated mean hemoglobin level was comparatively lower than the hemoglobin level of our patient $(15.1 \mathrm{~g} / \mathrm{dL})$.

As Case 1 [7] and Case 2 [8] patients were diagnosed with pernicious anemia, the deficiency of vitamin B12 was managed by parenteral (subcutaneous/intramuscular) vitamin B12 supplementation. Other published case reports $[9,10]$ have not mentioned about the presence of pernicious anemia in the patient, and thus, it can be assumed that they were managed by oral vitamin B12 supplementation. Similarly, the vitamin B12 deficiency in our patient was managed by oral supplementation of vitamin B12, vitamin B6, and folic acid.

After conducting a literature review of the published case reports which were similar to our case, it was found that the information available from the published literature is not sufficient to understand the relationship between severity and cause of vitamin B12 deficiency and its effect on serum HCY level. One of the meta-analysis though supported an association between the elevated HCY levels and increased risk of cardiovascular disease (CVD) [16]. Even it is proposed that HCY levels can be considered as a marker rather than a risk factor as the impact of vitamin supplementation does not significantly reduce the risk of CVD. Furthermore, other factors such as folic acid and/or vitamin B6 (pyridoxine) deficiency, deficiency of enzymes required for HCY metabolism or other genetic factors, and diseases or drugs should be considered in patients with moderate vitamin B12 deficiency having severe hyperhomocysteinemia.

The highlight of this case was the clinical pharmacist's intervention. On day 2, ticagrelor (antiplatelet agent) and a low molecular weight heparin (LMWH), i.e. enoxaparin (anticoagulant) were added to the regimen. The patient was already receiving an antiplatelet agent (clopidogrel $75 \mathrm{mg}$ ) in combination with aspirin $(150 \mathrm{mg})$. This possibly could have increased the risk of bleeding in the patient. Hence, clopidogrel was advised to STOP as ticagrelor is a better antiplatelet agent. Furthermore, the dose of aspirin was reduced at the time of discharge of the patient because aspirin above $100 \mathrm{mg}$ decreases the efficacy of ticagrelor. It has been clearly mentioned in the Food and Drug Administration black box warning [17] and NICE guidelines [18] that aspirin should be given at a low dose (75-100 mg) when administered in combination with ticagrelor. Benefits of ticagrelor over clopidogrel are briefly described in Table 2 [19].

Table 1: Comparative features of various published case reports with the current case study [7-10]

\begin{tabular}{|c|c|c|c|c|c|}
\hline Parameters & Case 1 [7] & Case 2 [8] & Case 3 [9] & Case $4[10]$ & Case 5 (present) \\
\hline Age (years) & 39 & 27 & 24 & 32 & 38 \\
\hline Gender & Male & Male & Male & Female & Male \\
\hline Past history & Hypothyroidism & None & None & $\begin{array}{l}\text { Gestational diabetes mellitus } \\
\text { and amenorrhea since } 6 \\
\text { months }\end{array}$ & $\begin{array}{l}\text { Jaundice } 3 \text { years back. } \\
\text { Family history of IHD }\end{array}$ \\
\hline ECG & $\begin{array}{l}\text { ST-segment } \\
\text { elevation }\end{array}$ & $\begin{array}{l}\text { ST-segment } \\
\text { elevation }\end{array}$ & $\begin{array}{l}\text { ST-segment } \\
\text { elevation }\end{array}$ & $\begin{array}{l}\text { Sinus rhythm with } \\
\text { symmetrical T-wave inversion }\end{array}$ & ST-segment elevation \\
\hline $\begin{array}{l}\text { Coronary } \\
\text { angiography }\end{array}$ & Performed & Performed & Performed & Performed & Performed \\
\hline RBC morphology & $\begin{array}{l}\text { Macrocytic, } \\
\text { pernicious Anemia }\end{array}$ & $\begin{array}{l}\text { Macrocytic, } \\
\text { pernicious anemia }\end{array}$ & $\begin{array}{l}\text { Macrocytic, } \\
\text { hyperchromic }\end{array}$ & $\begin{array}{l}\text { Microcytic and macrocytic } \\
\text { with hypochromia }\end{array}$ & $\begin{array}{l}\text { Normochromic, } \\
\text { normocytic }\end{array}$ \\
\hline $\begin{array}{l}\text { Hemoglobin and } \\
\text { RBC indices }\end{array}$ & $\begin{array}{l}11.2 \mathrm{~g} / \mathrm{dL} \text {, Elevated } \\
\text { RBC indices }\end{array}$ & $\begin{array}{l}11.2 \mathrm{~g} / \mathrm{dL}, \text { Elevated } \\
\mathrm{RBC} \text { indices }\end{array}$ & $\begin{array}{l}10 \mathrm{~g} / \mathrm{dL} \text {, Elevated } \\
\mathrm{RBC} \text { indices }\end{array}$ & $11 \mathrm{~g} / \mathrm{dL}$ & $\begin{array}{l}\text { 15.1g/dL Borderline } \\
\text { high RBC indices }\end{array}$ \\
\hline Serum vitamin B12 & $\begin{array}{l}\text { Very low } \\
\text { (not mentioned) }\end{array}$ & $\begin{array}{l}158 \mathrm{pg} / \mathrm{ml} \text { Folate: } \\
12.1 \mathrm{ng} / \mathrm{ml}(>3)\end{array}$ & $48 \mathrm{pg} / \mathrm{ml}$ & $\begin{array}{l}\text { Low } \\
\text { (value not mentioned) }\end{array}$ & $89 \mathrm{pg} / \mathrm{ml}$ \\
\hline $\begin{array}{l}\text { Serum HCY } \\
\text { Treatment }\end{array}$ & $\begin{array}{l}105 \mu \mathrm{mol} / \mathrm{L} \\
\text { A (325 mg), } \\
\text { C ( } 600 \mathrm{mg}) \\
\text { UFH bolus+Epti. } \\
\text { Infusion+vit. } \\
\text { B12 (SC) }\end{array}$ & $\begin{array}{l}105 \mu \mathrm{mol} / \mathrm{L} \\
\mathrm{W}+\mathrm{vit} . \mathrm{B} 12 \\
(\mathrm{IM} \text { and SC) + } \\
\mathrm{A}+\mathrm{M}+\mathrm{L}+\mathrm{Ep}\end{array}$ & $\begin{array}{l}16 \mu \mathrm{mol} / \mathrm{L} \\
\text { Strep. }+ \\
\text { LMWH+antiplatelet } \\
\text { agents+vit. B12+FA }\end{array}$ & $\begin{array}{l}28.48 \mu \mathrm{mol} / \mathrm{L} \\
\text { Angioplasty stenting. } \\
\mathrm{A}+\mathrm{C}+\text { inj. E. FA+vit. } \mathrm{B} 12 \text { and } \\
\text { iron supplements }\end{array}$ & $\begin{array}{l}15.65 \mu \mathrm{mol} / \mathrm{L} \\
\text { Strep. + A+antiplatelet } \\
\text { agents+Ator. + } \\
\text { M+Nico. + E (tab) vit. } \\
\text { B12+FA+vit. B6 orally }\end{array}$ \\
\hline
\end{tabular}

SC: Subcutaneous, IM: Intramuscular, Inj: Injection, Tab.: Tablet, pg/ml: Picogram per milliliter, g/dl: Gram/deciliter, $\mu$ mol/L: Micromoles per liter, A: Aspirin, Ator: Atorvastatin, C: Clopidogrel, E: Enoxaparin, Epti.: Eptifibatide, Ep.: Eplerenone, FA: Folic acid, L: Lisinopril, LMWH: Low molecular weight heparin, M: Metoprolol, Nico. : Nicorandil, Strep.: Streptokinase, UFH: Unfractionated Heparin, Vit. B12: Vitamin B12, Vit. B6: Vitamin B6, W: Warfarin, RBC: Red blood cell 
Table 2: Comparison of pharmacological features of ticagrelor and clopidogrel [19]

\begin{tabular}{|c|c|c|}
\hline Parameter & Ticagrelor & Clopidogrel \\
\hline Platelet inhibition & More & Less \\
\hline $\begin{array}{l}\text { P2Y12 ADP } \\
\text { receptor binding }\end{array}$ & Reversible & Irreversible \\
\hline Loading dose & $180 \mathrm{mg}$ & $300-600 \mathrm{mg}$ \\
\hline $\begin{array}{l}\text { Peak effect } \\
\text { (after loading dose) }\end{array}$ & $2 \mathrm{hrs}$ & $6 \mathrm{hrs}$ \\
\hline Half life & $9 \mathrm{hrs}$ & $0.5 \mathrm{hr}$ \\
\hline $\begin{array}{l}\text { Time to recover } \\
\text { platelet function } \\
\text { after ceasing } \\
\text { medication }\end{array}$ & 2-3 days & 5 days \\
\hline $\begin{array}{l}\text { Combination } \\
\text { with aspirin } \\
\text { for secondary } \\
\text { prevention of } \\
\text { ischemic attacks }\end{array}$ & $\begin{array}{l}\text { More effective, reduced } \\
\text { rate of death from } \\
\text { vascular causes or } \\
\text { myocardial infarction } \\
\text { or stroke without } \\
\text { significant increased } \\
\text { risk of bleeding }\end{array}$ & $\begin{array}{l}\text { Not as effective as } \\
\text { Ticagrelor + Aspirin } \\
\text { combination, } \\
\text { higher rate of } \\
\text { death from } \\
\text { vascular causes } \\
\text { or myocardial } \\
\text { infarction or stroke }\end{array}$ \\
\hline
\end{tabular}

\section{CONCLUSION}

Mild elevation of HCY levels caused by severe vitamin B12 deficiency was managed by oral vitamin B complex supplementation. Vitamin B12 deficiency and HCY level evaluation can be considered in young patients having AMI without any traditional risk factors. In our case, the patient was having a family history of ischemic heart disease and followed the Mediterranean diet which could be considered as a risk factor for coronary artery disease and vitamin B12 deficiency, respectively. Hence, in such young patients, it is necessary to check the vitamin B12 and HCY levels at regular intervals to avoid vascular complications.

\section{REFERENCES}

1. Souad L, Cherifa A, Dalila N. The effects of homocysteine on plasma biochemical parameters and aortic matrix metalloproteinases activities. Int J Pharm Pharm Sci 2014;7(1):459-62.

2. Moselhy SS, Demerdash SH. Plasma homocysteine and oxidative stress in cardiovascular disease. Dis Markers 2003-2004;19(1):27-31.
3. Subhapriya S, Tomi L, Padmanaban VC. Atherosclerosis: Critical role of oxidation and inflammation. Int J Pharm Pharm Sci 2013;5 Suppl 4:6-8.

4. Selhub J. Homocysteine metabolism. Annu Rev Nutr 1999;19:217-46.

5. Spence JD, Bang H, Chambless LE, Stampfer MJ. Vitamin intervention for stroke prevention trial: An efficacy analysis. Stroke 2005;36:2404-9.

6. Nygård O, Vollset SE, Refsum H, Stensvold I, Tverdal A, Nordrehaug JE et al. Total plasma homocysteine and cardiovascular risk profile. The hordaland homocysteine study. JAMA 1995;274(19):1526-33.

7. Hankey GJ, Eikelboom JW. Homocysteine and vascular disease. Lancet 1999;354:407-13

8. Refsum H, Yajnik CS, Gadkari M, Schneede J, Vollset SE, Orning L, et al. Hyperhomocysteinemia and elevated methylmalonic acid indicate a high prevalence of cobalamin deficiency in Asian Indians. Am J Clin Nutr 2001;74(2):233-41.

9. Marinou K, Antoniades C, Tousoulis D, Pitsavos C, Goumas G Stefanadis C. Homocysteine: A risk factor for coronary artery disease? Hellenic J Cardiol 2005;46:59-67.

10. Blum A, Lupovitch S, Khazim K, Peleg A, Gumanovsky M, Yeganeh $\mathrm{S}$, et al. Homocysteine levels in patients with risk factors for atherosclerosis. Clin Cardiol 2001;24(6):463-6.

11. Yajnik CS, Deshpande SS, Lubree HG, Naik SS, Bhat DS, Uradey BS, et al. Vitamin B12 deficiency and hyperhomocysteinemia in rural and urban Indians. J Assoc Physicians India 2006;54:775-82.

12. Wierzbicki AS. Homocysteine and cardiovascular disease: A review of the evidence. Diab Vasc Dis Res 2007;4(2):143-50.

13. Litsky J, Meller SM, Patel C. Acute myocardial infarction in a young patient with severe hyperhomocysteinemia secondary to pernicious anemia. Cath Lab Digest 2013;21(7). Available from: http://www. cathlabdigest.com/articles/Acute-Myocardial-Infarction-YoungPatient-Severe-Hyperhomocysteinemia-Secondary-Pernicious.

14. Melhem A, Desai A, Hofmann MA. Acute myocardial infarction and pulmonary embolism in a young man with pernicious anemia-induced severe hyperhomocysteinemia. Thromb J 2009;7:5.

15. Rathod S, Sayyed A, Mahale J, Gaikwad V. Young myocardia infarction: Secondary to vitamin B12 deficiency. Int J Recent Trends Sci Technol 2015;15(3):521-3.

16. Shamkani WA, Jafar NS, Narayanan SR, Rajappan AK. Acute myocardial infarction in a young lady due to vitamin B12 deficiency induced hyperhomocysteinemia. Heart Views 2015;16(1):25-9.

17. Medication Guide Brilinta ${ }^{\circledR}$ (brih-LIN-tah) (ticagrelor) Tablets $1^{\text {st }}$ ed. 2016. Available from: http://www.fda.gov/downloads/Drugs/ DrugSafety/UCM264220.pdf. [Last cited on 2016 Jan 06].

18. Ticagrelor for the Treatment of Acute Coronary Syndromes Guidance and Guidelines NICE. Nice.Org.Uk; 2011. Available from: https:// www.nice.org.uk/Guidance/TA236. [Last cited on 2016 Jun 06].

19. Praveen I, Christopher C. New antiplatelet drugs for acute coronary syndrome. Aust Prescr 2014;37(6):182-6. 